\title{
Efficiency Enhancement of a Dual-axis Solar PV Panel Tracker Using Water-Flow Double Glazing Technique
}

\author{
Farag Mahel Mohammed* Jamal Abdul-Kareem Mohammed** \\ Rasha Ali Nouri*** \\ *,**,*** Department of Electromechanical Engineering / University of Technology / Baghdad/Iraq \\ *Email: drfaragmahel@yahoo.com \\ ** Email: jamalshwesh@ gmail.com \\ *** Email: eng.rasha1992@yahoo.com
}

(Received 26 October 2017; accepted 5 December 2017)

https://doi.org/10.22153/kej.2018.12.008

\begin{abstract}
The fall angle of sun rays on the surface of a photovoltaic PV panel and its temperature is negatively affecting the panel electrical energy produced and efficiency. The fall angle problem was commonly solved by using a dual-axis solar tracker that continually maintains the panel orthogonally positioning to the sun rays all day long. This leads to maximum absorption for solar radiation necessary to produce maximum amount of energy and maintain high level of electrical efficiency. To solve the PV panel temperature problem, a Water-Flow Double Glazing WFDG technique has been introduced as a new cooling tool to reduce the panel temperature. In this paper, an integration design of the water glazing system with a dual-axis tracker has been accomplished and experimentally tested in order to enhance the PV panel efficiency, especially at hot climates. The proposed glazing system can simultaneously perform two functions, firstly, working as a cooling tool for reducing the stored heat in the PV panel during its work and secondly as an optical filter for sun light spectrum. Optimum design factors with their levels for the glazing system were calculated according to Taguchi method. Test experiments were carried out in Baghdad city on the 20th and 21st July 2016 on the tracker with and without using the WFDG system. The obtained results show that, the PV panel temperature with using the WFDG system was significantly dropped by $44 \%$ and its efficiency increased maximally by $36.6 \%$ at solar irradiance of $1213 \mathrm{~W} / \mathrm{m}^{2}$ as compared with conventional one.
\end{abstract}

Keywords: Dual-axis, PV panel, solar tracker, WFDG system, optical filte, efficiency.

\section{Introduction}

The solar energy may be utilized in two ways: by collecting the solar radiation and using it in a thermal system or by collecting and converting it directly to electrical energy using a solar Photovoltaic PV system. Initially, type of the employed PV cells affects the PV module electrical performance. Depending upon the kind of these cells and climatic circumstances, a standard PV module transforms (6-20) \% of the falling solar radiation into electricity. The residue of solar radiation is transferred into heat, which elevates the module temperature and reduces its efficiency [1]. One of the main obstacles that face the operation of PV panel is the drop in the electric converting efficiency of its cells. The maximum efficiency values of typical monocrystalline PV panel are between (11-15)\% [2]. This defect motivated scientists and researchers to enhance the efficiency of the PV panel.

The outputs of the PV devices are influenced by different environmental factors, such as module temperature, solar incident irradiance, and solar spectrum distribution. It was found that the PV solar cells work best in cold weather than hot weather. In hot weather, the temperature of the PV cells elevates because of its exposure to 
excess in the solar radiation and ambient temperatures. It was found that the maximum production of the output electric power and efficiency of the solar PV cells significantly reduces with the cell temperature increase [1]. Thus, the PV cells temperature in hot summer days may be reached more than $70^{\circ} \mathrm{C}$. An efficient way to minimize the rate of thermal fall of the PV module and improve its electrical efficiency is by decreasing its surface operating temperature. This could be accomplished by using a cooling technique for the PV module. In the present study, a Water-Flow Double Glazing WFDG technique that is used has been proposed as a new cooling tool to enhance the PV module efficiency.

On the other side, practically, it was found that the power produced by a PV module is changed with the solar spectrum variation, at a given temperature and irradiance level, over the incident light wavelength range [3]. The second aim of this paper is the building of the WFDG chamber in which used as an optical filter. This filter will be optimized for maximum PV system performance. Both of the acrylic glazing sheets and water inside the glazing system could be used as optical filters for solar spectrum; permits to the VIS part of the solar spectrum and remove the IR part responsible for heating the solar cell.

The cooling and filtering mechanisms represented by the WFDG technique are commonly used for building windows. This technique could efficiently benefit in designing a high efficient solar PV system. The same technique, with some appropriate modifications, may be used here, firstly to control the heat transfer and reducing the operating temperature across PV panel surfaces and secondly filtering the useful solar spectrum to generate electricity across the PV panel terminals and thus improving the overall energy efficiency. The proposed WFDG system in the present work was combined a dual-axis solar tracker system.

\section{Factors Affecting PV Panel Efficiency}

The solar PV panel efficiency depends on various factors such as the solar intensity or radiation, the panel operating temperature, and the dust falling on the panel surface [2]. There are many methods might be used to improve the efficiency of the solar PV panel: 1- Solar tracking, 2- PV panel cooling, 3- Dust cleaning of the panel surface, and 4- Antireflective Coating ARC of the panel surface. The present work focuses on the first two methods.
When the solar PV cells are exposing to greater amounts of the sunlight, they generate more electric power. The amount of this power is depending on minimizing the fall angle of the sun rays on the PV panel surface. This could be achieved by using a single or dual-axis tracker. The dual-axis tracker continually faces the sun because it can move in two different directions to ensure falling sun ray's perpendicular to the PV panel surface all day from sunrise to sunset, which makes the panel, exposes to larger amount of sun rays and produces maximum power output. Therefore, the dual-axis tracker is considered as one of the more effective ways to improve the PV module performance.

Another factor affecting the PV panel efficiency is the cooling technique. Basically, the cooling is divided into two types: passive cooling that utilizes natural convection and conduction for extracting the heat, and active cooling that wastes energy via using fans, pumps, etc. In the two types of cooling, the air and water are commonly used as mediums. However, the cooling by water is better than air for extracting the heat energy from the PV panel at hot climate. It enables the PV panel to work best at elevated levels of temperature and permits, more efficiently, employing the waste heat recovery [4]. Many studies had been carried out, in the literature, on cooling the PV systems. The Hybrid Photovoltaic/Thermal PV/T solar system is one of the most popular methods for cooling the PV panels nowadays. Furushima and Nawata [5] utilized a siphonage as a cooling tool to develop a PV system and evaluated the increase in the PV panel performance during the summer. Abdolzadeh and Ameri [6] used spraying water above PV cells to reduce the cell's solar reflection and enhance the PV panel performance. Zhu et al. [7] used a water immersion cooling system in a high concentration PV system to avoid the cell degradation. Gang et al. [8] worked an experimental study on a heat pipe PV/T system performance and confirmed that the system efficiency was improved with the use of cooling by circulated water. eldin et al. [9] used the solar Chimney concept to improve the cooling system efficiency by using the Particle Swarm Optimization PSO. Bahaidarah et al. [10] experimentally studied the performance of a PV module by integrating a water circulated heat exchanger on its back surface. 


\section{Water-Flow Double Glazing System}

The Glazing term is commonly called double glazing (window panes) and more or triple window panes, its space is evacuated or filled with gas so as to decrease heat transfer in the buildings facades. Nowadays, the advanced glazing is widespread in the advanced building facades [11]. The incoming solar energy falling on the glazing windows was not invested until an air or water-flow through double panes was proposed by Chow et al. [12] to cool window panes in the buildings and blocks the window heat from being transferred into the building interior.

The WFDG system is basically made up of a chamber with two glass panes surrounding a void filled by water. When this system is merged within a facade, it absorbs the solar energy to be utilized later as a hot water. The space within the two panes represents a thermal insulator, reduces the amount of energy consumed by an airconditioning system in the building. The WFDG system permits flowing pure water stream across the panes space. A specific cooling device should be used to cool down this water via removing its heat captured. The cold water reduces the glazing panes temperature and obstructs the sun radiation from raising the heat of any devices placed at the back of the glazing system. The water heated by the absorbed solar radiation might be utilized for domestic applications. The flow and the speed of circulating water depend on the cooling need in a specific place at a given time. The WFDG chamber should be connected in the system, sequentially with a feed supply, heat exchanger, water tank, returning pipes, and water pump to control the flow rate of water.

The WFDG system has been used with interest in exteriors: curtain walls, facades, skylights and rooftops. The preferred characteristics of this system may be completely invested, so as to minimize the consumption of electric energy. These advantages made the WFDG technique is efficiently employing in solving the energy inefficiencies problems and could be improved and reapplied to enhance the efficiency of the solar PV panel which is suffering from absorptive heating that decreases its electrical efficiency by about $5 \%$ for each degree rise in its operating temperature above $50^{\circ} \mathrm{C}$ [1]. In the present work, the WFDG chamber is proposed to be placed on the front surface of the PV panel.

\section{Thermal Behavior of WFDG System}

When the solar radiation reaches the outer layer of the WFDG chamber, part of incident solar flux is reflected, another part is transmitted and the rest is absorbed. The absorbed radiation heats up the water confined inside the chamber. The total energy reaches the occupied areas of the PV panel under the chamber is the sum of convective and conductive heat transfers plus the solar energy transmittance which measures the proportion of solar energy that finally ends up in the interior.

The WFDG chamber creates an isothermal shield in the glazed surface of the PV's envelope with a temperature lower than its internal temperature. The WFDG system allows transmitting heat from the panel occupied areas into the chamber due to the temperature gradient between the PV inside and the chamber. Fig. 1 demonstrates the thermal behavior of the WFDG system. The energy per unit time absorbed Q $\left(\mathrm{W} / \mathrm{m}^{2}\right)$ by the water equates the summation of energies acting by [13]; (part of the sun radiation energy absorbed by the glazing + radiation energy transmitted through the glazing + energy exchange with the outside air due to radiation and ordinary/forced convection + energy exchange with the panel inside due to radiation and ordinary convection).

$Q=\dot{m} C_{p}\left(T_{w}-T_{\text {ext }}\right)=G A \alpha_{w}+\tau G-$

$h_{\text {ext }} A\left(T_{w}-T_{\text {ext }}\right)-h_{\text {int }} A\left(T_{w}-T_{\text {int }}\right)$

where $\dot{m}$ is the water mass flow rate, $\mathrm{kg} / \mathrm{s} ; C_{p}$ is the water specific heat, J/kg.K; $T_{w}$ is the chamber water temperature; $T_{\text {ext }}$ and $T_{\text {int }}$ are the temperature outside and inside, respectively; $G$ is the solar irradiance, $\mathrm{W} / \mathrm{m}^{2} ; A$ is the window surface directed orthogonally to the sun rays direction; $\alpha_{w}$ is the absorption factor of the water chamber; $\tau$ is the solar transmittance; $h_{\text {ext }}$ and $h_{\text {int }}$ are the exterior and interior heat transfer coefficients, respectively.

\section{Optical Filters}

The solar spectrum approximately has $2 \%$ Ultraviolet (UV), 47\% Visible (VIS) and 51\% Infrared (IR) of the total solar energy. Therefore, the sun VIS light and IR radiation constitutes the major fraction of solar radiation reaching earth atmosphere. The solar crystalline PV cells utilize portion of the IR and UV spectrum and full of the VIS spectrum [14]. In the literature, many researchers deal with the effect of the solar spectrum on the performance of the PV cells. 
Huld et al. [3] proposed an empirical model to study this effect. They showed that the total effect of spectral variations was acting by an increase in output power by $1.5 \%$ for cadmium telluride and $0.4 \%$ for crystalline silicon, with respect to the standard test conditions.

It was found that the quantum efficiency of the crystalline PV solar cell is being in the range of wavelength $(300-1180) \mathrm{nm}$ of the sun's light. This range includes energy around $86 \%$ of the entire solar spectrum energy, the remaining is converting into heat that raises the solar PV cell temperature. Therefore, it is necessary to filter out the solar spectrum with wavelengths above the $1180 \mathrm{~nm}$ [14]. This could be accomplished by using an optical filter. The optical filter selectively transmits light in a certain range of color wavelengths, whereas preventing others.

Absorption and transmission of the sun radiation in the double glazing depends upon certain solar spectral properties of glass. Glazing panes has transmissivity depending on radiation's wavelength. In particular, clear glass is very transparent to VIS and Near-Infrared NIR wavelengths. However, due to the spectral properties of water, it is very transparent to VIS wavelengths but opaque to NIR wavelengths [14]. One of the superior glazing materials is the acrylic plastic sheets. The acrylic sheet is highly transparent, flexible and has great resistance to breakage. It is an excellent material which can replace glass. It is lightweight, with only half weight of glass for the same size, and it is virtually unaffected by nature. The acrylic sheet actually has optical properties equal to or better than the ordinary glass. The clear acrylic sheet transmits $93 \%$ of total light compared to approximately $88 \%$ for ordinary plate glass. The acrylic transmits up to $92 \%$ of VIS light and reflects $8 \%$. It blocks $98 \%$ of UV light [14]. Therefore, it could be used with the solar PV panels as an optical filter to substantially increase their efficiency. In the literature, many hybrid solar PV/T systems had been designed with optical filters. Some studies had shown that clean fluids like water and organic liquids could be used with the solar PV systems as optical filters [1517]. A. Qahtan et al. [18] had examined the possibility of using the Sustainable Glazed Water Film SGWF as spectrum filter for buildings in the Torrid Zone. The study showed the effectiveness of this technique in minimizing the transmittance of the solar heat (IR) and maximizing transmittance of the daylight (VIS), when $70 \%$ of the short-wave IR radiation ranging (1300 - 2500) $\mathrm{nm}$ was absorbed by a thin water film. The water film does not obstruct the VIS sun light, but actually raises its transmittance. It concluded that the SGWF is suitable in enhancing the visual and thermal conveniences and decreasing the cooling loads in buildings equipped with glazing facades. When the concentrated solar radiation hits upon the optical filter, the IR spectrum get absorbed by the water and then falls on the solar cells, the remained VIS light would be transmitted into the PV cells and transferred into electrical energy as shown in Fig. 2. This configuration blocks the excessive rise in the solar cell temperature. Therefore, the solution of glazing that was typically used in the building industry could be applied here to be compatibly working with the PV module, which by combining a glazing chamber with circulating water; it will minimize the heat transmittance, increase the capability of blocking the IR radiation and keep the glass transparency for VIS light. The circulating water varies the transmittance and the solar factor of the assembly, between the other characteristics, extremely depending on the water temperature.

\section{Experimental Setup \\ 5.1. The Solar Tracker}

To construct dual-axis solar tracker unit, some mechanical prerequisites should be considered. All requirements including a $28 \mathrm{~W}, 12 \mathrm{~V}$ Monocrystalline solar PV panel are pointed out in the experimental setup shown in Fig. 3. The tracking system is depending in its work on two rotational axis movements, vertical and horizontal.

Since the solar tracking is a repetitive activity, the PLC could be used to control the tracking system. A PLC of (LS/GLOFA-G7MDR20U/DC) type was used and programmed in the Ladder diagram language using GMWIN 4.0 software. To control the PV panel motion, four light dependent resistors LDRs as light sensors of Cds photoresistor type were used to sense the sun's position and continuously direct the panel to receive maximum solar radiation. Two $12 \mathrm{~V}$ DC worm geared motors with $2.4 \mathrm{rpm}$ speed and $5 \mathrm{~N}$.m torque were used to drive the solar tracker to the desired direction. The control system components and its related connections are shown in Fig. 4.

\subsection{The WFDG System}

The WFDG system shown in Fig. 3 consists of six components: 1-WFDG chamber, 2- water 
tank, 3- water pump, 4- heat exchanger, 5- inlet and outlet water pipes, and 6- thermostat. The block diagram of the WFDG system is clarified in Fig. 5. The WFDG chamber has been built of double panes of clear acrylic plastic sheets, filled with distilled water and fixed in close contact with the PV panel surface. In the present work, experimentally, it was found that using an acrylic sheet with $2 \mathrm{~mm}$ thick permits to transmit $98.66 \%$ of the total light compared to $92.4 \%$ for ordinary plate glass. Therefore, the total average solar energy transmittance is about $6 \%$ more for acrylic sheet than ordinary glass. As a result, acrylic sheets of $2 \mathrm{~mm}$ thick may be effectively used in constructing the proposed glazing chamber. Three parameters; WFDG chamber thickness, WFDG chamber position, and flow rate of pumping water were considered with three values for each, to optimize the WFDG system design using Taguchi technique. Cold water inters one side of the WFDG chamber across two inlets to make regular distribution and departs it as a hot water from one outlet on the other side of the chamber. The water in the chamber is circulated to heat exchanger via a $(12 \mathrm{~V}),(0.18 \mathrm{~A}) \mathrm{DC}$ water pump. The flow and speed of the circulating water depend on the cooling need in the specific place at a certain time.

The heat captured by the chamber is transported to a water tank to reduce thermal oscillations of the glass panes due to the sun radiation. The tank hot water is pumped to the heat exchanger to cool it. The cooled water inters the chamber through its inlet pipes to cool down the PV panel temperature. The heat exchanger was buried in a basin filled with mud to reduce the temperature of the hot water passing through it. It is a simple idea derived from the ground heat exchanger technique used for cooling buildings [19]. This method of cooling the heat exchanger without using fan is low cost and consumes less electric energy. Under this condition, the temperature of the cool water reached $(25-30)^{\circ} \mathrm{C}$. Therefore, it could be say, the WFDG system had been successfully used as a cooling tool. The system contains a thermostat ranging $(30-90)^{\circ} \mathrm{C}$ to control the solar panel temperature; its sensor touches the rear surface of the PV panel to sense its temperature. The thermostat was adjustable at $40^{\circ} \mathrm{C}$. When the panel temperature elevates over above $40^{\circ} \mathrm{C}$, the thermostat activates the water pump to run for a time around (5-10) min for cooling the water and then stops. Removing the excessive heat from the PV panel via using the WFDG system might be invested to save energy; transfer it from cool demand areas (PV panel) to hot demand areas, i.e. domestic utilization.

\section{Taguchi Optimization Method}

Two tests on 19th and 20th June 2016 were carried out. Parameters like the solar radiation intensity, ambience temperature, PV panel surface temperature, rated values of panel voltage and current, and water pump flow rate were measured during one hour for each test. The tests were carried out at solar noon with highest values of solar irradiance and ambient temperature. In this paper, analyzing the effect of the WFDG system on the PV panel performance using the Taguchi Design of Experiments DOE method was studied. Experimental results were collected and analyzed.

Taguchi method [20] is a systematic approach to analyze and explain the collected data and verify the study aims. In this method, the designer could find the close optimal solution to the proposed problem. This may be used as an initial value for a standard optimization technique. Selecting a proper design of the WFDG system depends on the optimum results obtained by using the DOE method. Three parameters or factors; WFDG chamber thickness (A), pump flow rate (B) which can be regulated by using a rheostat, and WFDG chamber position distance (C) above the solar panel surface, with their three levels would be optimally designed for enhancing the PV panel performance represented by the three responses; solar irradiance efficiency, solar panel temperature, and panel voltage. Table 1 illustrates the three factors with their three levels. Choosing the control parameters and analyzing their effects on the output responses is considered as the more necessary step in the DOE method. Choosing a suitable Taguchi orthogonal array for the control factors and levels would give the optimum combination of levels. In this work, the three impact factors or parameters were considered with $\mathrm{L}_{9}\left(3^{3}\right)$ orthogonal array [20] as listed in Table 2.

\subsection{Signal to noise $S / N$ Ratio}

The $\mathrm{S} / \mathrm{N}$ ratio represents the most significant parameter in the Taguchi design methodology. There is several formulas of $\mathrm{S} / \mathrm{N}$ ratio to get the optimum results. The goal of the current work is how to enhance the solar panel efficiency. This could be achieved by raising the panel voltage and reducing its temperature with the best efficiency of solar irradiance, i.e. the $\mathrm{S} / \mathrm{N}$ ratio "the smallest 
is best to make the system response as small as possible" would be used for panel temperature data and the $\mathrm{S} / \mathrm{N}$ ratio "the largest is best to make the response as large as possible" would be used to find the irradiance efficiency and panel voltage data. These ratios were calculated as follows [20]:

$S / N$ ratio $=-10 \log _{10}\left(x^{2}\right)$

When, the smallest is best

$S / N$ ratio $=-10 \log _{10}\left(1 / x^{2}\right)$

When, largest is best

Where, $x$ is the critical response performance parameters; solar irradiance efficiency, PV panel temperature, or PV panel voltage. The values of the calculated $\mathrm{S} / \mathrm{N}$ ratio for all nine experimental results were recorded in Table 3 for each parameter of the system response. The panel temperature values were measured after using the WFDG chamber when $56^{\circ} \mathrm{C}$ panel temperature was chosen as a reference value measured before using the chamber. The irradiance efficiency acts the ratio of irradiance measured on the PV panel surface under the chamber to its value measured over the chamber surface.

\subsection{Analysis of Means ANOM}

The ANOM is an analytic tool of data taken from the orthogonal array experiments. The ANOM values could be found from the average values of $\mathrm{S} / \mathrm{N}$ ratio at a certain level for any factor. These values were listed as in Table 4 for the three performance responses: irradiance efficiency, panel temperature, and panel voltage. For example, for the effect of the WFDG chamber thick factor on the solar intensity shown in Table 4 , the level 1 value could be represented by the calculated mean $\mathrm{S} / \mathrm{N}$ ratios; first three rows of the $\mathrm{L}_{9}$ array $(-0.149,-0.142,-0.134)$ listed in Table 3 which depends upon the corresponding array (first three experiments for level 1 and factor A) shown in Table 2. The same scenario was reapplying on other factors and levels. The optimal level pointed out by the underlined value shown in Table 4 represents the average value of $\mathrm{S} / \mathrm{N}$ ratio required to get the best performance. Therefore, the optimum level combination for the solar irradiance efficiency response is $\mathrm{A}_{1} \mathrm{~B}_{3} \mathrm{C}_{1}$, which equivalent to factor $\mathrm{A}$ with level 1 , factor $\mathrm{B}$ with level 3, and factor $\mathrm{C}$ with level 1 , meaning $(1 \mathrm{~cm}$ WFDG chamber thickness, $28.2 \mathrm{~cm}^{3} / \mathrm{sec}$ water flow rate, and $0 \mathrm{~cm}$ chamber position). Also, for the PV panel temperature, the optimal arrangement level is $A_{3} B_{2} C_{1}$, i.e. ( $2 \mathrm{~cm}$ thickness, $42.3 \mathrm{~cm}^{3} / \mathrm{sec}$ water flow rate, and $0 \mathrm{~cm}$ position), while the optimum levels arrangement for the PV panel voltage is $\mathrm{A}_{2} \mathrm{~B}_{3} \mathrm{C}_{1}$, that means $(1.5 \mathrm{~cm}$ thickness, $28.2 \mathrm{~cm}^{3} / \mathrm{sec}$ water flow rate and $0 \mathrm{~cm}$ position). The (max-min) column shown in Table 4 represents the difference between the highest and lowest $\mathrm{S} / \mathrm{N}$ values for the three levels and each factor, e.g. for solar irradiance efficiency with factor $\mathrm{A}$, the $(\max -\mathrm{min})=(-0.1416)-(-$ $0.2006)=0.0591$. The same manner can be used to find the remained column values for other two factors $(0.0591,0.0151$, and 0.0012$)$. This column is the more influential factor for choosing the system response parameters. It could be found according to the Rank parameter. The rank column is numbered from the highest to the lowest (max-min) value. So, from the rank value, it was found that the chamber thick (factor A) has more effectiveness on the irradiance efficiency than other two factors (B and then C), respectively. Same scenario can reapply to complete the (max-min) and rank columns in Table 4 for the other responses; the PV panel temperature and voltage. It can be noticed from the table that the position of the chamber (factor C) is the more influential factor on the temperature and voltage of the PV panel than other two factors (A and B).

Graphically, Fig. 6 shows the values of the mean of S/N ratios versus the levels and factors for the three system responses. It can be noted that level 1 for factor $\mathrm{C}$ (chamber position) has mean $\mathrm{S} / \mathrm{N}$ ratios with optimum values for the three responses, which gives the maximum efficiency of irradiance, minimum PV panel temperature, and maximum PV panel voltage. This means that, placing the chamber to be in touch with the PV panel cells surface is the best choice. To get maximum irradiance efficiency, levels $(1,3$, and 1) for the corresponding factors (A, B and C), respectively, were chosen. While the levels $(3,2$, and 1) for the corresponding factors (A, B, and C) could be used to obtain minimum panel temperature. Also, levels (2, 3, and 1) of the corresponding factors (A, B, and $\mathrm{C}$ ) are representing the optimal level values which give the maximum value of panel voltage that is the goal of the present work. Therefore, the WFDG system offers the highest enhancement of performance when the chamber thickness = $1.5 \mathrm{~cm}$, water flow rate $=28.2 \mathrm{~cm}^{3} / \mathrm{sec}$ and the chamber is directly placing on the panel surface. As a result, the WFDG chamber was constructing with $(l \times w \times t=43 \times 42 \times 1.5) \mathrm{cm}$ dimensions. Where, $l$ and $w$ represent the same corresponding dimensions of the PV panel surface. 


\subsection{Analysis of Variance ANOVA}

The ANOVA [20] is a statistical analysis tool used for analyzing the effect of the design factors on the overall difference of test results. The parameter which is statistically more important than others could be distinguished by the ANOVA tests. Table 5 illustrates the ANOVA analysis results. From the table, the sum of square of deviation SS column, due to any factor can be calculated according to following equation:

$S S=3 \sum_{i=1}^{n}\left(\eta_{i}-\eta_{m}\right)^{2}$

Where $\eta_{i}$ is the mean value of $\mathrm{S} / \mathrm{N}$ ratio for the $i^{\text {th }}$ experiments for the factors $\mathrm{A}, \mathrm{B}$ or $\mathrm{C}$ and levels, $\eta_{m}$ is the total mean values of $\mathrm{S} / \mathrm{N}$ ratios for any response which equal (sum of $\mathrm{S} / \mathrm{N}$ ratios divided by 9), $i$ is the number level for each factor, $n=3$ is the number of experiments at that level, e.g. for the irradiance response in the Table 4, the factor A value in three levels; $A_{1}, A_{2}$, and $A_{3}$ is equal to $S S=3\left[\left(\mathrm{~A}_{1}-\eta_{m}\right)^{2}+\left(\mathrm{A}_{2}-\eta_{m}\right)^{2}+\left(\mathrm{A}_{3}-\eta_{m}\right)^{2}\right]$. The SS for other factors could be calculated in the same manner. For any factor, the degrees of freedom d.f is equal to the number of factor's levels minus one $=3-1=2$. The d.f value for the total sum of squares is equal to the number of rows in the designed matrix $-1=9-1=8$. The d.f value of the error is equal to the d.f of the total sum of squares minus the sum of the d.f's for all factors $=8-6=2$. The mean square value $=\mathrm{MS}=$ SS/d.f. The F ratio in Table 5 can be calculated as the ratio of mean square to the error mean square for any factor $=$ MS/EMS. The contribution column in the table could be found by dividing the SS value for each factor by the total sum of SS. From the contribution column, e.g. for the solar irradiance efficiency, it was found that factor A has the significant effect on the system response, that highly contributes to the total sum of squares by about; $(0.005473 / 0.005823) \times 100=93.99 \%$. So, it has the largest influence on the irradiance efficiency than other factors, followed by factor B with $5.86 \%$ and then $C$ with $0.04 \%$. Also, for the panel temperature response, the factor $\mathrm{C}$ has the largest contribution of $65.04 \%$ followed by factor $\mathrm{B}$ of $12.00 \%$ and then $\mathrm{C}$ with $11.82 \%$. In same manner, factor $\mathrm{C}$ is the significant factor for panel voltage followed by factor A and then B. In other word, according to the contribution value, the WFDG chamber thickness factor has the greatest influence on the solar irradiance process than others factors, pumping water flow rate and then chamber position. Also, the chamber position is the more effect factor on both of the solar panel temperature and voltage than other two factors.
From Tables 4 and 5, it can be concluded that the ANOM and ANOVA results are perfectly matched, and three concepts can be deduced, that is the chamber configuration would be:

1. $1 \mathrm{~cm}$ thickness has more effect on irradiance efficiency, however it doesn't cause minimum PV panel temperature, moreover, it is not adequate to achieve a maximum panel voltage.

2. $2 \mathrm{~cm}$ thickness verifies a minimum panel temperature, but it doesn't achieve the maximum panel voltage; this is because of the waste increase in the sunlight irradiance.

$3.1 .5 \mathrm{~cm}$ thickness achieves a maximum output panel voltage, the more influence parameter on the panel efficiency. This configuration can decrease the value of irradiance waste less than using $2 \mathrm{~cm}$ chamber thickness.

Also, it can be noticed from tables that level 3 for factor $\mathrm{B}$ and level 1 for factor $\mathrm{C}$ give the maximum output panel voltage. As a result, the proposed WFDG system can achieve the highest performance enhancement with specifications; $1.5 \mathrm{~cm}$ chamber thick, $28.2 \mathrm{~cm}^{3} / \mathrm{sec}$ water flow rate and $0 \mathrm{~cm}$ chamber distance (the chamber is directly touched the panel surface). This arrangement reduces the irradiance waste in the sunlight, increases the heat rejected, reduces the PV panel temperature, increases the panel voltage, and consequently increases the panel efficiency. Therefore, the chamber could be optimally built with $(43 \times 42 \times 1.5) \mathrm{cm}$ dimensions.

\subsection{Confirmation Test}

The confirmation test represents the final step of DOE method. This test has been conducted at optimal levels. Since, the optimum levels for each response were introduced. The optimal values of the $\mathrm{S} / \mathrm{N}$ ratio under the optimal conditions $\eta_{\text {opt }}$ can be found as follows [20]:

$\eta_{\text {opt }}=\eta_{m}+\sum_{i=1}^{n}\left(\eta_{i}-\eta_{m}\right)$

This test had been used for comparing the values of the experimental $\mathrm{S} / \mathrm{N}$ ratios with the predicted $\mathrm{S} / \mathrm{N}$ ratios. The total mean value of the $\mathrm{S} / \mathrm{N}$ ratio $\eta_{m}$ was found according to its values labeled in Table 3 for each performance response. The $\eta_{i}$ values act the underlying values of the mean $\mathrm{S} / \mathrm{N}$ ratio at optimum conditions as in Table 4. $n$ is the number of design factors. Therefore, the predicted $\mathrm{S} / \mathrm{N}$ values were found and the confirmatory test results were tabulated as in Table 6. It can be shown that, the experimental and predicted test results are close together with an error does not exceed $3.9 \%$. 


\section{Results and Discussion}

The performance experimental results for the dual-axis solar tracking unit combined with the WFDG system were collected. The WFDG chamber was designed with optimum factors; 1.5 $\mathrm{cm}$ chamber thick, $28.2 \mathrm{~cm}^{3} / \mathrm{sec}$ water flow rate and $0 \mathrm{~cm}$ chamber position to achieve the highest efficiency. To find the electrical efficiency of the solar PV panel combined with the glazing system, some parameters, like the panel voltage $V_{p v}$ and current $I_{p v}$, the temperature of the panel surface, the ambience temperature, the inlet/outlet temperature of flowing water, water flow rate, and solar radiation intensity $G_{s}$ were measured. The performance of the overall system is depending on sun's position with respect to the PV panel. The PV panel tracks the greatest sun light intensity via its light sensors according to a Ladder program loaded into the PLC. The solar panel surface area $A_{s}$ is $0.1806 \mathrm{~m}^{2}$. All the necessary specifications for the solar PV panel and WFDG system are listed in Table 7. The output power, $P_{\text {out }}$ and input power, $P_{\text {in }}$ for the solar PV panel and its electric efficiency $\eta_{\text {elec }}$ had been found by [1]:

$\eta_{\text {elec }}=\frac{P_{\text {out }}}{P_{\text {in }}}=\frac{V_{p v} I_{p v}}{G_{s} A_{s}}$

In the present work, the obtained readings were conducted in two test cases. These readings were recorded using the measurements devices listed in Table 8. They are distributed on two successive days, the19th and 20th June 2016 from sunrise to sunset. In the first test day, only the dual-axis tracking system with no use of the WFDG unit system (case 1) was applied. In the second test day, the tracking system was integrated with the WFDG system (case 2). Fig. 7 shows the history of the incident solar irradiance on the PV panel on 19th and 20th June 2016 for the two cases, respectively. The figure shows the increase in the irradiance through the period 7:00AM $-1: 30 \mathrm{PM}$ and the decrease after 1:30PM for both system cases (tracker without and with the glazing system). It could be seen that the difference in the solar irradiance for the two cases is relatively small and not exceed $1.8 \%$. The rise in the irradiance and ambient temperature causes increase in the PV panel temperature. In Fig. 8, the panel temperature in case 1 at test day had been increased within 7:00AM-1:00PM among $(40.1-59.7)^{\circ} \mathrm{C}$ because of the ambient temperature increase around $(34.3-46.5)^{\circ} \mathrm{C}$. The panel temperature, after 1:00PM decreases as the ambient temperature decreases, while in case 2, the panel temperature becomes between (36.5 $38.8)^{\circ} \mathrm{C}$. This range is attributed to the use of glazing system (case 2), which tries to maintain the panel temperature approximately around $40^{\circ} \mathrm{C}$ by about $(3.5-1.2)^{\circ} \mathrm{C}$ reduction as the panel receives irradiance not exceed $1150 \mathrm{~W} / \mathrm{m}^{2}$ and around $(2-0.2)^{\circ} \mathrm{C}$ reduction with irradiance value more than $1150 \mathrm{~W} / \mathrm{m}^{2}$. The electric power taken from the PV panel depends upon the measured values of the panel voltage and current. This power basically is proportional to the sun irradiance. In Fig. 9, the solar panel generates maximum output power values at a time among 12:30PM - 1:30PM. The panel power would be decreased gradually after 1:00PM when the irradiance decreases. The output PV panel power with case 2 had been elevated maximally by about $18.66 \%$, and averagely about $14.96 \%$ comparing with case 1 . The maximum output power of the PV panel was $27.78 \mathrm{~W}$ in the case 2 when maximum voltage and current were $20.84 \mathrm{~V}$ and $1.333 \mathrm{~A}$, while it was $23.41 \mathrm{~W}$ in the case 1 when maximum voltage and current were $18.7 \mathrm{~V}$ and 1.252A. The electric efficiency curve of the solar panel was shown in Fig. 10. It is shown that the efficiency increases with time until 1:00PM and then decreases with the irradiance decrease. The figure shows that the maximum efficiency is $12.7 \%$ in case 2 , and $10.5 \%$ in case 1 . So, it can be concluded that the efficiency in the case 2 is higher than case 1, maximally by around $20.9 \%$ and averagely $16.5 \%$. This is because of being the panel temperature in case 2 was decreased maximally by about $34.6 \%$ and averagely $22.4 \%$ comparing with case 1 .

Second experimental tests were conducted in 20th and 21st in July 2016 for finding out the temperature effect along the daytime on the PV panel efficiency in the tracking system mode for the two cases as shown in Fig.11. In this month, Baghdad city is characterizing by its highest temperatures through the year. It could be shown that the PV panel temperature of the system in case 1 was within $(46-71.2)^{\circ} \mathrm{C}$ through the period 7:00AM-1:00PM as the ambient temperature was around $(36.1-52)^{\circ} \mathrm{C}$, respectively and decreased after 1:00PM, while, in the case 2, the panel temperature decreased into $(37.7-39.8)^{\circ} \mathrm{C}$. The maximum electric efficiency of the PV panel had been $12.7 \%$ at solar irradiance of $1213 \mathrm{~W} / \mathrm{m}^{2}$ in the case 2 , whereas, it was $9.3 \%$ in the case 1 . As a result, reducing the panel temperature in case 2 maximally by $44 \%$ and averagely $34.2 \%$ as compared with case 1 , causes the solar panel efficiency to be increased in the case 2 more than case 1 , maximally by about $36.6 \%$ and averagely by $31.4 \%$, respectively. 
Table 1,

The proposed factors and levels.

\begin{tabular}{llll}
\hline Factors & Level-1 & Level-2 & Level-3 \\
\hline A- WFDG chamber thickness, cm & 1 & 1.5 & 2 \\
B- Water flow rate, $\mathrm{cm}^{3} / \mathrm{sec}$ & 87.3 & 42.3 & 28.2 \\
C- WFDG chamber position, cm & 0 & 1 & 2 \\
\hline
\end{tabular}

Table 2。

Numbering of experiments using L9 orthogonal array.

\begin{tabular}{llll}
\hline \multirow{2}{*}{ Exp No. } & \multicolumn{2}{c}{ Factors and levels } \\
\cline { 2 - 4 } & $\begin{array}{l}\text { WFDG chamber thickness, A } \\
\text { Level }\end{array}$ & $\begin{array}{l}\text { Water flow rate, B } \\
\text { Level }\end{array}$ & $\begin{array}{l}\text { WFDG chamber position, C } \\
\text { Level }\end{array}$ \\
\hline 1 & 1 & 1 & 1 \\
2 & 1 & 2 & 2 \\
3 & 1 & 3 & 3 \\
4 & 2 & 1 & 2 \\
5 & 2 & 2 & 3 \\
6 & 2 & 3 & 1 \\
7 & 3 & 1 & 3 \\
8 & 3 & 2 & 1 \\
9 & 3 & 3 & 2 \\
\hline
\end{tabular}

Table 3,

$\mathrm{S} / \mathrm{N}$ ratio values of the experimental results.

\begin{tabular}{lllcllc}
\hline \multirow{2}{*}{ Exp No. } & \multicolumn{2}{l}{ Irradiance efficiency } & Panel temperature & \multicolumn{3}{c}{ Panel voltage } \\
\cline { 2 - 7 } & Value, $\%$ & S/N ratio, $\mathbf{~ d B}$ & Value, ${ }^{\circ} \mathbf{C}$ & S/N ratio, $\mathbf{~ d B}$ & Value, $\mathbf{V}$ & S/N ratio, dB \\
\hline 1 & 98.30 & -0.149 & 52.0 & -34.320 & 19.35 & 25.734 \\
2 & 98.38 & -0.142 & 54.3 & -34.696 & 19.07 & 25.607 \\
3 & 98.47 & -0.134 & 54.5 & -34.728 & 19.05 & 25.598 \\
4 & 98.10 & -0.167 & 54.4 & -34.712 & 19.15 & 25.643 \\
5 & 98.17 & -0.160 & 54.6 & -34.744 & 19.10 & 25.621 \\
6 & 98.25 & -0.153 & 46.0 & -33.255 & 19.70 & 25.889 \\
7 & 97.61 & -0.210 & 54.7 & -34.760 & 19.02 & 25.584 \\
8 & 97.74 & -0.199 & 40.6 & -32.171 & 19.08 & 25.612 \\
9 & 97.80 & -0.193 & 54.0 & -34.648 & 19.06 & 25.602 \\
\hline
\end{tabular}

Table 4,

Mean S/N ratios for different factors (Underlined value represents the optimum level).

\begin{tabular}{|c|c|c|c|c|c|c|}
\hline \multirow{3}{*}{ Factor } & \multicolumn{3}{|c|}{ Average of $\mathrm{S} / \mathrm{N}$ ratio values } & \multirow{3}{*}{ Max-Min } & \multirow{3}{*}{ Rank } & \multirow{3}{*}{ Optimal levels } \\
\hline & Level-1 & Level-2 & Level-3 & & & \\
\hline & \multicolumn{3}{|c|}{ Irradiance efficiency, \% } & & & \\
\hline $\begin{array}{l}\text { A- WFDG chamber thickness, } \\
\mathrm{cm}\end{array}$ & $\underline{-0.1416}$ & -0.1601 & -0.2006 & 0.0591 & 1 & \multirow{3}{*}{$\mathrm{A}_{1} \mathrm{~B}_{3} \mathrm{C}_{1}$} \\
\hline $\mathrm{B}-\mathrm{Water}$ flow rate, $\mathrm{cm}^{3} / \mathrm{sec}$ & -0.1752 & -0.1669 & -0.1602 & 0.0151 & 2 & \\
\hline \multirow[t]{2}{*}{ C- WFDG chamber position $(\mathrm{cm})$} & -0.1669 & -0.1672 & -0.1682 & 0.0012 & 3 & \\
\hline & & Panel temp & re, ${ }^{\circ} \mathrm{C}$ & & & \\
\hline $\begin{array}{l}\text { A- WFDG chamber thickness, } \\
\mathrm{cm}\end{array}$ & -34.5813 & -34.2370 & -33.8594 & 0.7220 & 3 & \multirow{4}{*}{$\mathrm{A}_{3} \mathrm{~B}_{2} \mathrm{C}_{1}$} \\
\hline B- Water flow rate, $\mathrm{cm}^{3} / \mathrm{sec}$ & -34.5973 & -33.8701 & -34.2103 & 0.7271 & 2 & \\
\hline \multirow[t]{2}{*}{ C- WFDG chamber position, $\mathrm{cm}$} & -33.2486 & -34.6853 & -34.7438 & 1.4953 & 1 & \\
\hline & & $\underline{\text { Panel vo }}$ & & & & \\
\hline $\begin{array}{l}\text { A- WFDG chamber thickness, } \\
\mathrm{cm}\end{array}$ & 25.6462 & $\underline{25.7178}$ & 25.5994 & 0.1184 & 2 & \multirow{3}{*}{$\mathrm{A}_{2} \mathrm{~B}_{3} \mathrm{C}_{1}$} \\
\hline B- Water flow rate, $\mathrm{cm}^{3} / \mathrm{sec}$ & 25.6537 & 25.6131 & $\underline{25.6966}$ & 0.0835 & 3 & \\
\hline C- WFDG chamber position, $\mathrm{cm}$ & $\underline{25.7448}$ & 25.6176 & 25.6009 & 0.1439 & 1 & \\
\hline
\end{tabular}


Table 5,

Results of ANOVA.

\begin{tabular}{|c|c|c|c|c|c|}
\hline Factors & $\begin{array}{l}\text { Sum of squares } \\
\text { SS }\end{array}$ & $\begin{array}{l}\text { Degree of freedom } \\
\text { d.f }\end{array}$ & $\begin{array}{l}\text { Mean } \\
\text { squares } \\
\text { MS }\end{array}$ & $\begin{array}{l}\text { F ratio } \\
\%\end{array}$ & $\begin{array}{l}\text { Contribution } \\
\%\end{array}$ \\
\hline \multicolumn{6}{|c|}{ Irradiance efficiency, \% } \\
\hline A- WFDG chamber thickness, cm & 0.005473 & 2 & 0.0027363 & 841.6179 & 93.99 \\
\hline B- Water flow rate, $\mathrm{cm}^{3} / \mathrm{sec}$ & 0.000341 & 2 & 0.0001706 & 52.4685 & 5.86 \\
\hline C- WFDG chamber position, $\mathrm{cm}$ & 0.0000024 & 2 & 0.0000012 & 0.3674 & 0.04 \\
\hline Error mean square EMS & 0.0000065 & 2 & 0.00000325 & & 0.11 \\
\hline Total sum & 0.005823 & 8 & & & 100.00 \\
\hline \multicolumn{6}{|l|}{ Panel temperature, ${ }^{\circ} \mathrm{C}$} \\
\hline A- WFDG chamber thickness, cm & 0.7824 & 2 & 0.3912 & 1.0623 & 11.82 \\
\hline B- Water flow rate, $\mathrm{cm}^{3} / \mathrm{sec}$ & 0.7942 & 2 & 0.3971 & 1.0783 & 12.00 \\
\hline C- WFDG chamber position, $\mathrm{cm}$ & 4.3033 & 2 & 2.1517 & 5.8429 & 65.04 \\
\hline Error mean square, EMS & 0.7365 & 2 & 0.3683 & & 11.13 \\
\hline Total sum & 6.6164 & 8 & & & 100.00 \\
\hline \multicolumn{6}{|l|}{ Panel voltage, $\mathrm{V}$} \\
\hline A- WFDG chamber thickness, cm & 0.021328 & 2 & 0.0106642 & 2.4618 & 27.48 \\
\hline B- Water flow rate, $\mathrm{cm}^{3} / \mathrm{sec}$ & 0.010455 & 2 & 0.0052276 & 1.2068 & 13.47 \\
\hline C- WFDG chamber position, $\mathrm{cm}$ & 0.037174 & 2 & 0.0185872 & 4.2908 & 47.89 \\
\hline Error mean square EMS & 0.008664 & 2 & 0.0043318 & & 11.16 \\
\hline Total sum & 0.077622 & 8 & & & 100.00 \\
\hline
\end{tabular}

\section{Table 6,}

Results of Confirmation.

\begin{tabular}{lllll}
\hline Optimal Factors & & & & \\
\hline Factors & Optimal levels & Experimental values & Predicted values & Error, \% \\
\hline Irradiance efficiency, $\%$ & $\mathrm{~A}_{1} \mathrm{~B}_{3} \mathrm{C}_{1}$ & 98.47 & 98.47 & 0.00 \\
PV panel temperature, ${ }^{\circ} \mathrm{C}$ & $\mathrm{A}_{3} \mathrm{~B}_{2} \mathrm{C}_{1}$ & 40.6 & 42.29 & 3.9 \\
PV panel voltage, $\mathrm{V}$ & $\mathrm{A}_{2} \mathrm{~B}_{3} \mathrm{C}_{1}$ & 19.70 & 19.61 & 0.45 \\
\hline
\end{tabular}

Table 7,

PV panel and WFDG system specifications.

Solar PV panel specifications

\begin{tabular}{|c|c|c|c|}
\hline Parameter & Value & Parameter & Value \\
\hline Type & Mono-Si & \multicolumn{2}{|l|}{ Glazing chamber } \\
\hline Rated maximum power, $\mathrm{P}_{\max }$ & $28 \mathrm{~W}$ & Chamber dimensions & $(43 \times 42 \times 1.5) \mathrm{cm}$ \\
\hline Operating voltage, $\mathrm{V}_{\mathrm{mp}}$ & $21 \mathrm{~V}$ & Material & Acrylic glass \\
\hline Operating current, Imp & $1.33 \mathrm{~A}$ & Number of sheets & Two sheets \\
\hline Open-circuit voltage, $\mathrm{V}_{\mathrm{OC}}$ & $23.12 \mathrm{~V}$ & Sheet thickness & $2 \mathrm{~mm}$ \\
\hline Short-circuit current, IsC & $1.515 \mathrm{~A}$ & Thermal conductivity & $0.2 \mathrm{~W} / \mathrm{m} .{ }^{\circ} \mathrm{C}$ \\
\hline Efficiency, $\eta_{\text {ele }}$ & $15 \%$ & Chamber weight & $3.43 \mathrm{gm}$ \\
\hline Weight & $2.5 \mathrm{~kg}$ & \multicolumn{2}{|l|}{ Heat exchanger } \\
\hline Dimensions & $43 \times 42 \times 2.4 \mathrm{~cm}$ & Type & $\begin{array}{l}\text { Finned U tube air cooled } \\
\text { without fan installation frame }\end{array}$ \\
\hline No. of cells & 36 & Material & Copper pipes \\
\hline \multicolumn{2}{|c|}{ Standard Test Conditions, STC } & Aluminum foil & Hydrophilic or bare \\
\hline Air Mass, AM & 1.5 & Fines & Flat \\
\hline Cell Temperature, Tc & $25^{\circ} \mathrm{C}$ & Dimensions & $25 \times 25 \times 8 \mathrm{~cm}$ \\
\hline Solar Irradiance, $\mathrm{G}_{\mathrm{s}}$ & $1000 \mathrm{~W} / \mathrm{m}^{2}$ & Pipes external diameter & $1 \mathrm{~cm}$ \\
\hline
\end{tabular}

Table 8,

Specifications and accuracy of measurement devices.

\begin{tabular}{llll}
\hline Items & Model & Ranges & Accuracy \\
\hline & & - DCV: $400 \mathrm{~m} / 4 / 40 / 400 / 500 \mathrm{~V}$ & $\pm 0.8 \%$ \\
& & - ACV: $400 \mathrm{~m} / 4 / 40 / 400 / 500 \mathrm{~V}$ & $\pm 1.2 \%$ \\
Digital Multimeter & UT136C & - DCA: $400 / 4 \mathrm{~m} / 40 \mathrm{~m} / 400 \mathrm{~m} / 4 / 10 \mathrm{~A}$ & $\pm 1.0 \%$ \\
& & - ACA: $400 / 4 \mathrm{~m} / 40 \mathrm{~m} / 400 \mathrm{~m} / 4 / 10 \mathrm{~A}$ & $\pm 1.2 \%$ \\
& & - Temperature: $-40 \sim 1000$ & $\pm 2.5 \%$ \\
Digital thermometer & & - FREQ: $10 \mathrm{~Hz} \sim 10 \mathrm{MHz}$ & $\pm 0.5 \%$ \\
Solar power meter & PT-5 & Temperatures range: $-50 \sim 110{ }^{\circ} \mathrm{C}$ & $\pm 1^{\circ} \mathrm{C}$ \\
& SPM-1116SD & Irradiance range: $(0-2000) \mathrm{W} / \mathrm{m}^{2}$ & $\pm 10 \mathrm{~W} / \mathrm{m}^{2}$ \\
\hline
\end{tabular}




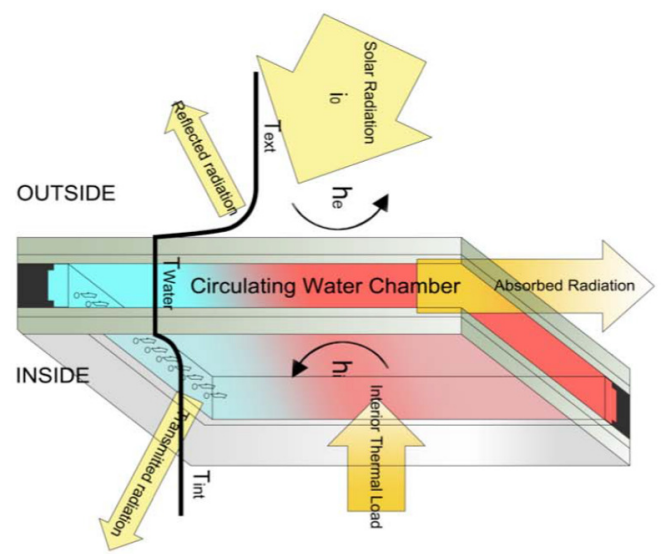

Fig. 1. Thermal performance of the WFDG system.

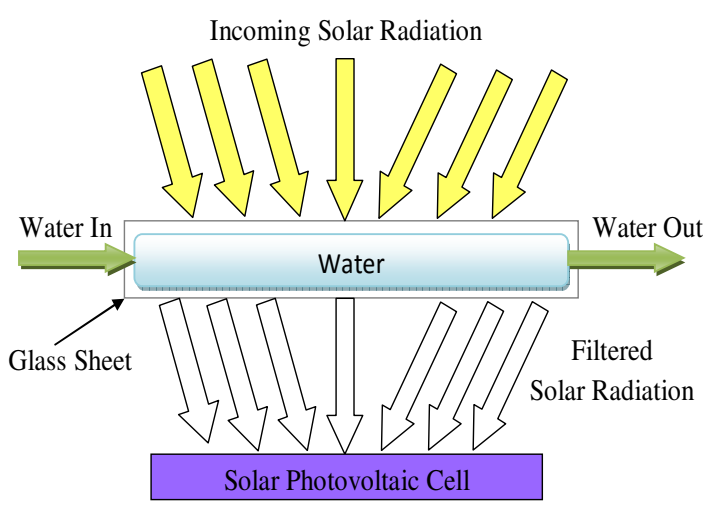

Fig. 2. WFDG system working as an optical filter.

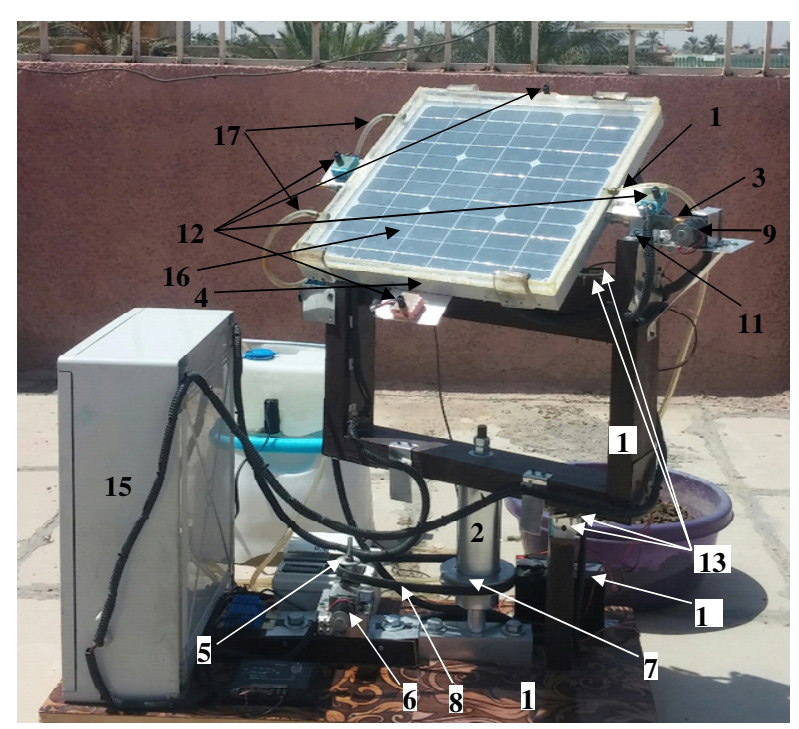

(a) front view

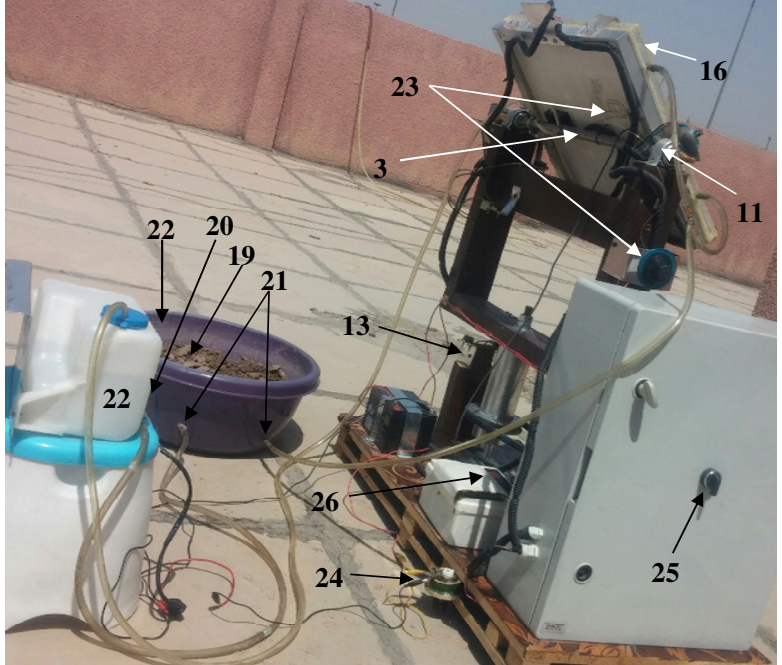

(b) back view

Fig. 3. Experimental setup of the whole system:1base, 2-cylindrical base, 3-central shaft, 4-PV panel, 5-driver pulley, 6- Motor M1, 7-driven pulley, 8-Vbelt, 9-Motor M2, 10-frame, 11-pillow block bearing, 12: LDR sensors S1-S4, 13: Limit switches LS1-LS4, 14-DC battery, 15-control board, 16WFDG chamber, 17-chamber inlets, 18-chamber outlet, 19-heat exchanger in mud basin, 20-water pump, 21-heat exchanger inlet/outlet, 22-water tank, 23-thermostst and its sensor, 24-Rheost, 25main switch S-SW, 26-digital meter.

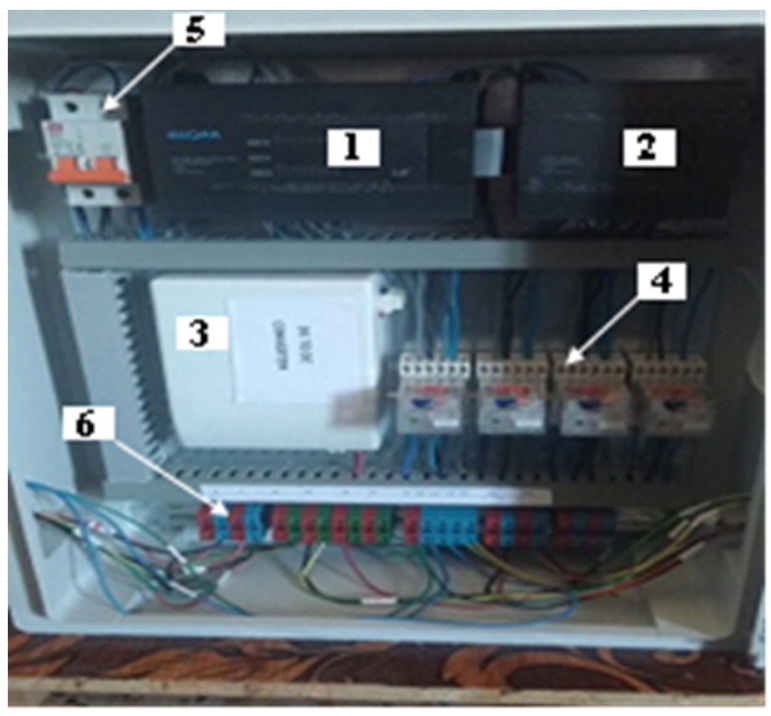

Fig. 4. Control system: 1-PLC, 2-A/D converter, 3DC/DC converter, system 4-relays, 5-main switch, 6-connectors. 


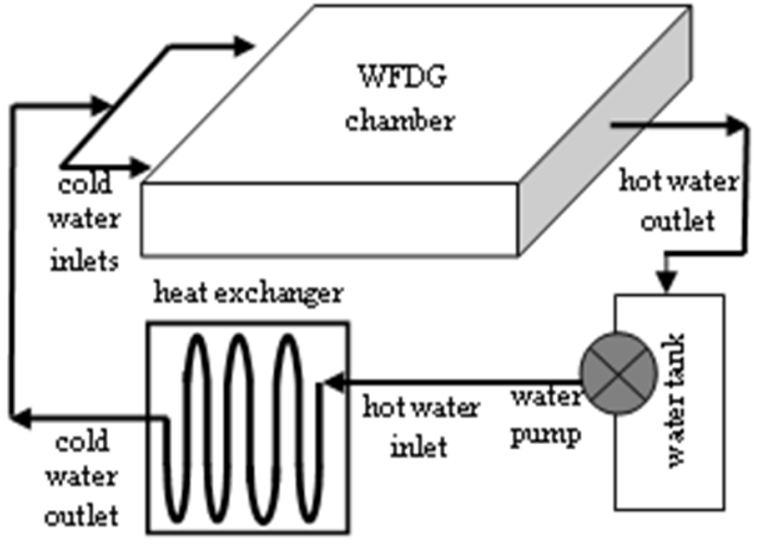

Fig. 5. Block diagram of the WFDG .

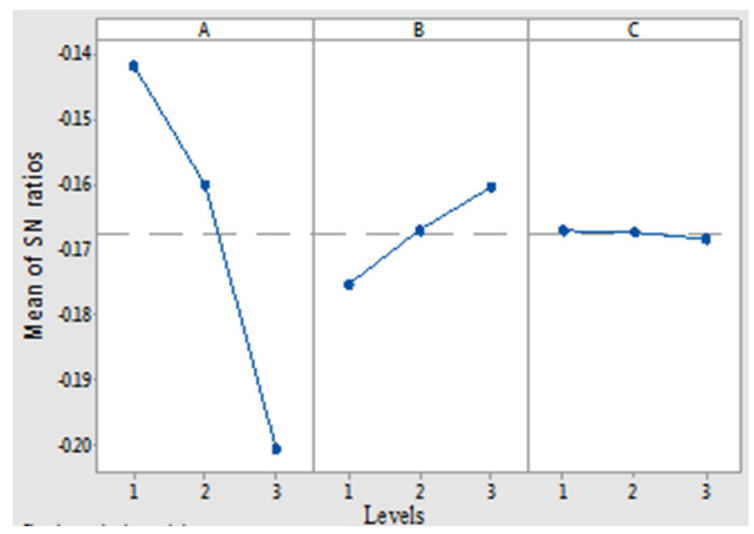

a) Solar irradiance efficiency

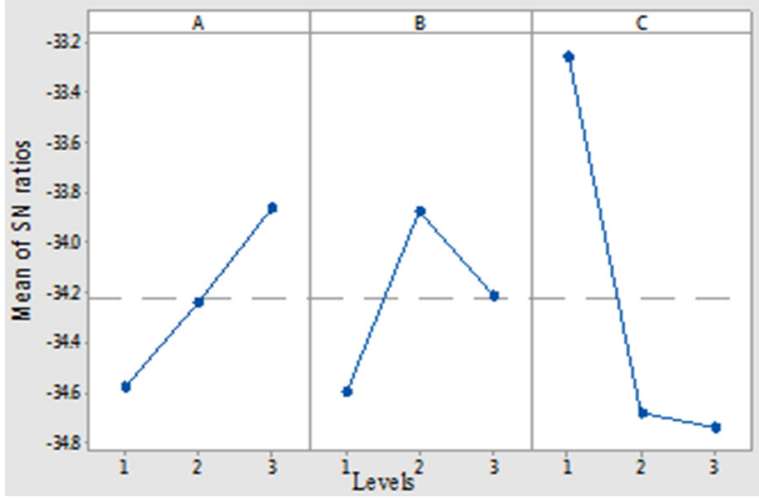

b) PV panel temperature

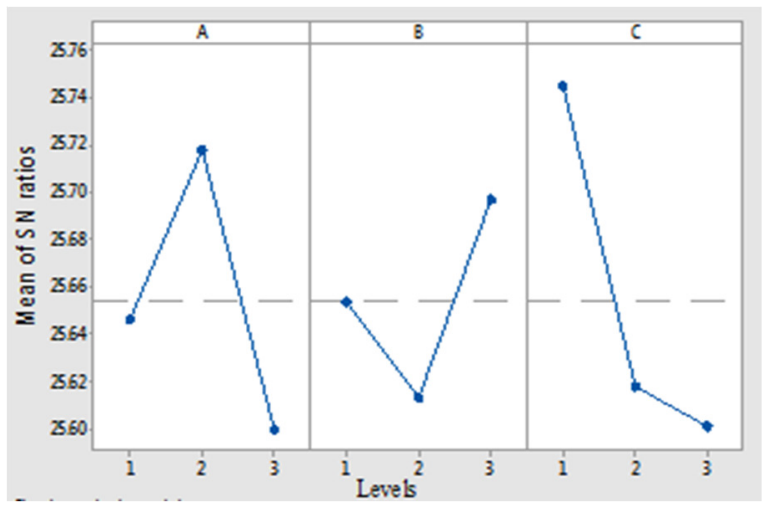

c) PV panel voltage

Fig. 6. The mean $\mathrm{S} / \mathrm{N}$ ratios with levels for various responses.

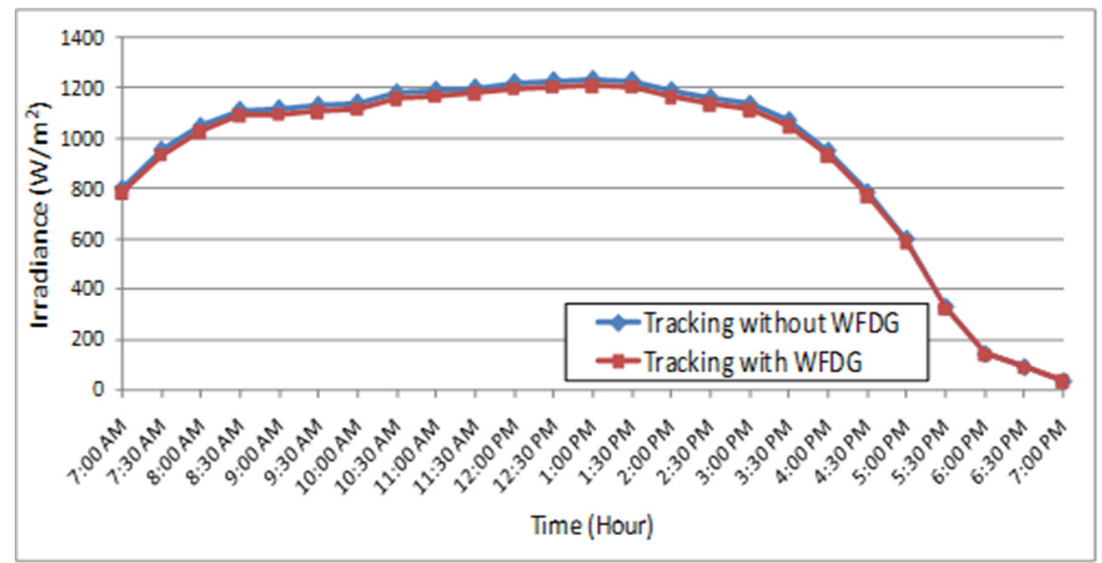

Fig. 7. Solar irradiance through day time. 


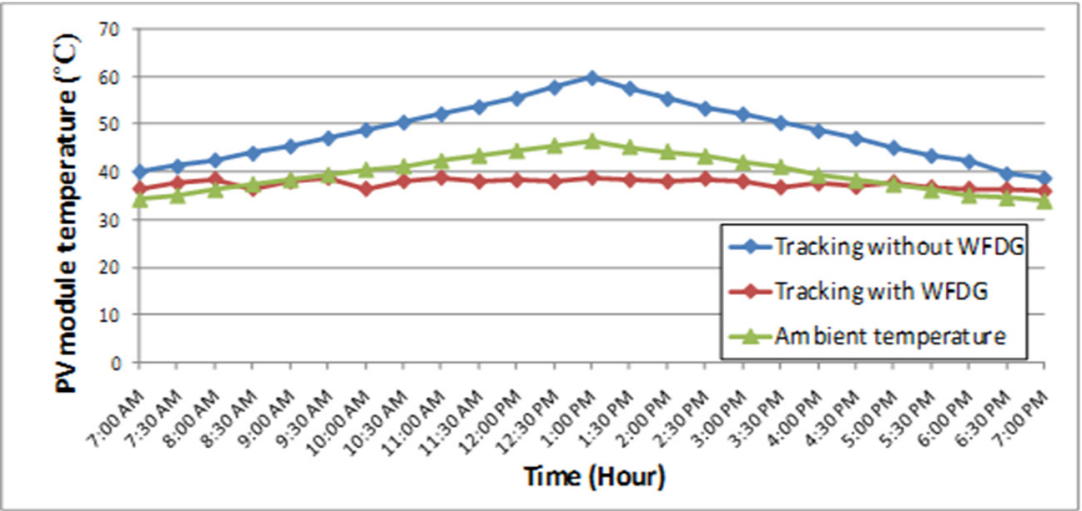

Fig. 8. Panel temperature through day time.

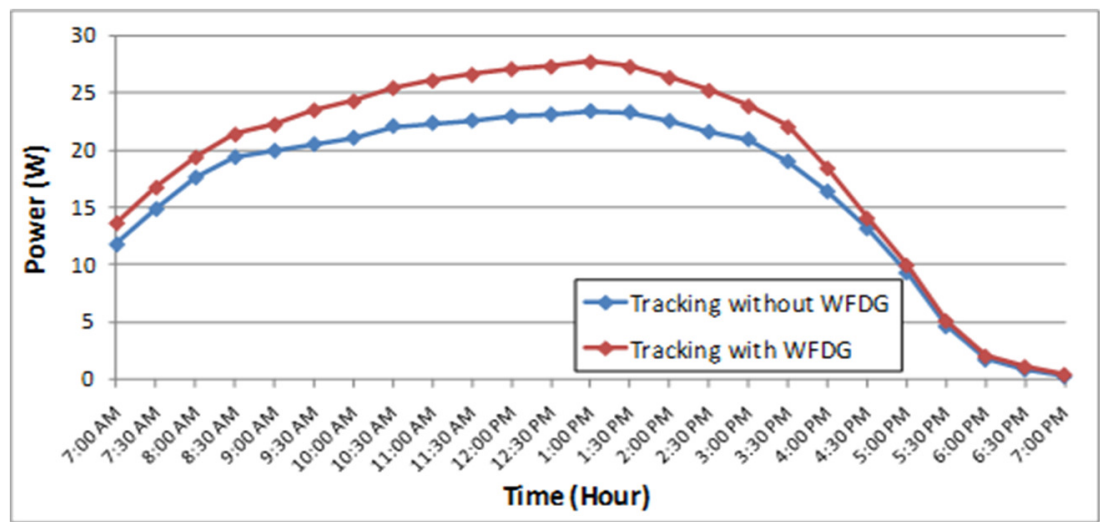

Fig. 9. Panel output power through day time.

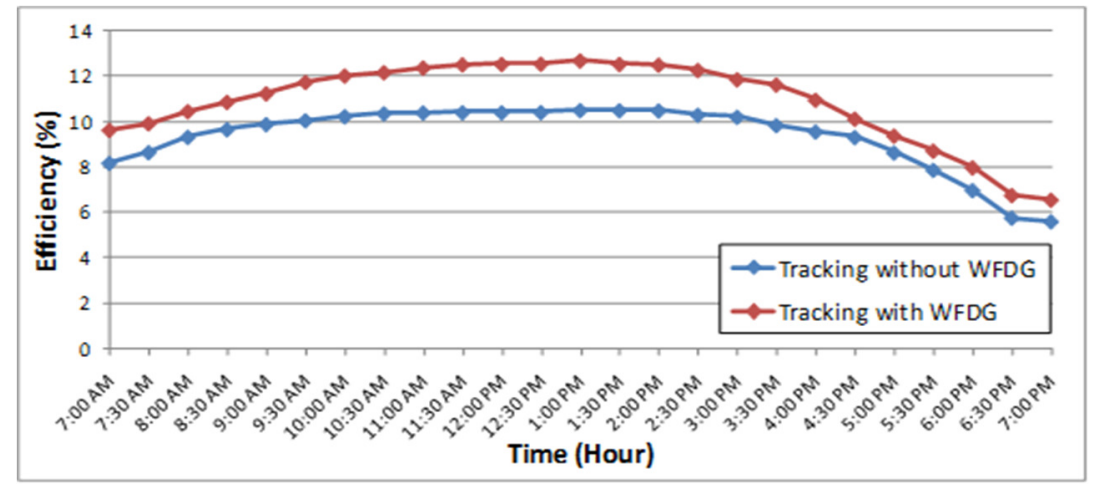

Fig. 10. Panel efficiency through day time.

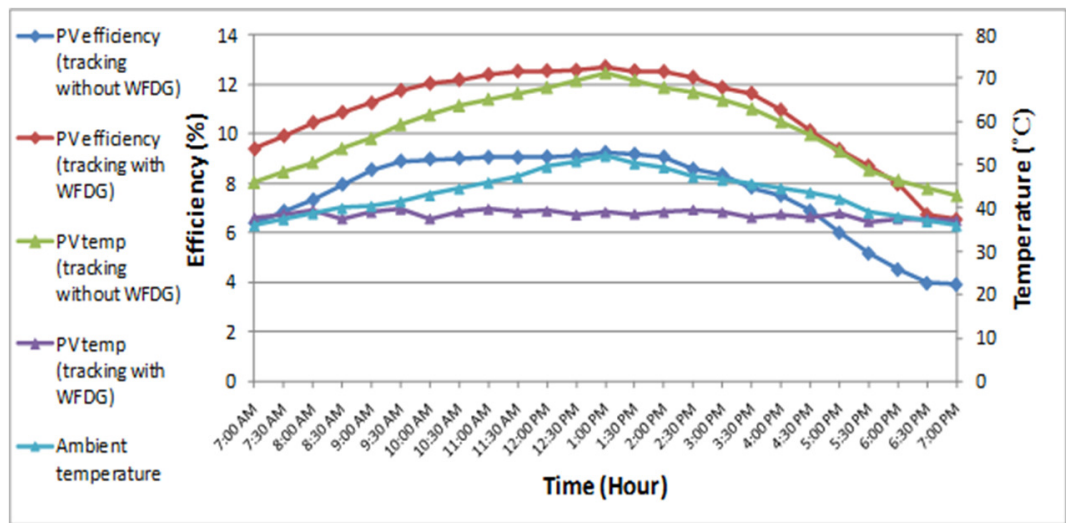

Fig. 11. Hourly performance comparison of the tracking PV panel system. 


\section{Conclusions}

In this paper, a water-flow double glazing WFDG system was designed, implemented, and integrated with a PLC-based automatic dual-axis solar PV tracker to enhance its electrical efficiency. Designing the experiments optimally was accomplished by Taguchi technique. Some conclusions might be extracted from the experimental results

1. The new WFDG technique wastes least possible amount of cooling water and consumes lowest electric energy than the traditional cooling methods.

2. Due to good spectral properties, the WFDG chamber could be used as an optical filter. Therefore, the WFDG system could execute two jobs, necessary to improve the efficiency of the PV panel; cooling down the PV panel and filtering out the incident sun's light on it.

3. The necessary factors of the WFDG system required for optimizing the performance of the PV panel determined by using the Taguchi DOE method were found as; $1.5 \mathrm{~cm}$ glazing chamber thickness, $28.2 \mathrm{~cm}^{3} / \mathrm{sec}$ pumping water flow rate, and $0 \mathrm{~cm}$ glazing chamber distance from the PV panel surface.

4. The position factor of the glazing chamber has greater effect on the temperature and voltage of the PV panel than the other two factors, while the glazing thickness factor is more effective on the irradiance than other two factors.

5. The WFDG system efficiency is reduced with the increase of the glazing position.

6 . The PV panel temperature in the combined system was maintained around $(36-40)^{\circ} \mathrm{C}$ and the maximum efficiency at $12.7 \%$ when the ambient exceed $50^{\circ} \mathrm{C}$. It was shown that the panel temperature reduction in the combined system was maximally about $44 \%$ and averagely $34.2 \%$, with respect to conventional system. This contributes to increase the solar panel efficiency maximally by $36.6 \%$ and averagely $31.4 \%$ at $1213 \mathrm{~W} / \mathrm{m}^{2}$ solar irradiance, comparing with the conventional system.

\section{References}

[1]Dubey, S., Sarvaiya, J. N. and Seshadri, B. 2013. Temperature Dependent Photovoltaic (PV) Efficiency and Its Effect on PV Production in the World A Review. PV Asia Pacific Conference 2012, Energy Procedia, Vol. 33, 311-321.
[2]C.S. Solanki, Solar Photovoltaics: Fundamentals, Technologies and Applications, 3rd Revised Edition Prentice Hall India Learning Private Limited 2015.

[3] T. Huld, T. Sample, E.D. Dunlop, A Simple Model for Estimating the Influence of Spectrum Variations on PV Performance, Proceedings of the 24th European Photovoltaic Solar Energy Conference, Hamburg, Germany, September 2009, pp. 3385-3389.

[4]F.G. Čabo, S. Nižetić, T.G. Marco, Photovoltaic Panels: A Review of the Cooling Techniques, Transactions of Famena $\mathrm{Xl}-$ 40(SI) (2016) 63-74.

[5] K. Furushima, Y. Nawata, Performance evaluation of photovoltaic power generation system equipped with a cooling device utilizing siphonage, Journal Solar Energy Engineering ASME 128 (2) (2005) 146-151.

[6] M. Abdolzadeh, M. Ameri, Improving the effectiveness of a photovoltaic water pumping system by spraying water over the front of photovoltaic cells, Renewable Energy 34 (1) (2009) 91-96.

[7] L. Zhu, R.F. Boehm, Y. Wang, C. Halford, Y. Sun, Water immersion cooling of PV cells in a high concentration system, Solar Energy Materials and Solar Cells 95 (2) (2011) 538545.

[8] P. Gang, F. Huide, Z. Huijuan, J. Jie, Performa nce study and parametric analysis of a novel heat pipe PV/T system, Energy 37 (1) (2012) 384-395.

[9] M. Sh-Eldin, F.O. Alghoul, A. Abouhnik, K. Sopian, M. Ae. Muftah, Predication of air velocity in Solar Chimney using RBFNN, Proceedings - 2012 7th IEEE International Conference on Computing and Convergence Technology ICCCT 2012, Seoul, 3-5 December 2012, pp. 976 - 979.

[10] H. Bahaidarah, A. Subhan, P. Gandhidasan, S. Rehman, Performance evaluation of a PV (photovoltaic) module by back surface water cooling for hot climatic conditions, Energy 59 (2013) 445-453.

[11] S. Ghoshal, S. Neogi, Advance Glazing System - Energy Efficiency Approach for Buildings a Review, Energy Procedia 54 (2014) 352-358.

[12] T.-T. Chow, C. Li, Z. Lin, Innovative solar windows for cooling-demand climate, Solar Energy Materials and Solar Cells 94 (2) (2010) 212-220.

[13] C. Li, T.-T. Chow, Water-filled double reflective window and its year-round 
performance, Procedia Environmental Sciences 11(2011)1039-1047.

[14] Handbook of Optics Vol. IV: Optical Properties of Materials, Nonlinear Optics, Quantum Optics, Third Edition, McGraw Hill, Inc. New York 2010.

[15] M.A.C. Chendo, M.R. Jacobson, D.E. Osbor $\mathrm{n}$, Liquid and thin film-filters for hybrid solar energy conversion system, Solar \& Wind Technology 4 (2) (1987) 131-138.

[16] S.S. Joshi, A.S. Dhoble, P.R. Jiwanapurkar, I nvestigations of Different Liquid Based Spectrum Beam Splitters for Combined Solar Photovoltaic Thermal Systems, ASME Journal of Solar Energy Engineering 138 (2) (2016).

[17] W.A.M. Al-Shohani, A. Sabouri, R. AlDadah, S. Mahmoud, H. Butt, Experimental investigation of an optical water filter for Photovoltaic/Thermal conversion module, Energy Conversion and Management, 111 (2016) 431-442.
[18] A. Qahtan, S.P. Rao, N. Keumala, The effectiveness of the sustainable flowing water film in improving the solar-optical properties of glazing in the tropics, Energy and Buildings 77 (2014) 247-255.

[19] G. Florides, S. Kalogirou, Ground heat exchangers - A review of systems, models and applications, Renewable Energy 32 (15) (2007) 2461-2478.

[20] C. Zang, M.I. Friswell, J.E. Mottershead, A review of robust optimal design and its application in dynamics, Computers and Structures 83 (4) (2005) 315-326. 


\section{تحسين كفاءةِ اللوح الشمسي المقتفي ثنائي المحاور بإستخدام الماء المتدفق ضمن غطائه الزجاجي المزدوج

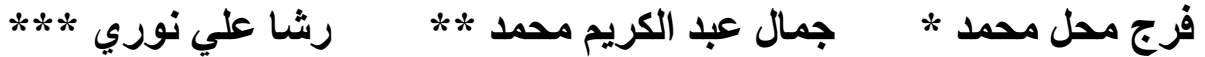

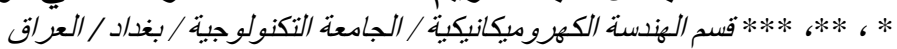

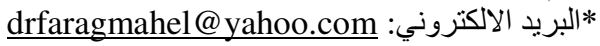

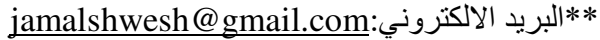 \\ eng.rasha1992@yahoo.com:البريد الالكتروني الكتروني:***}

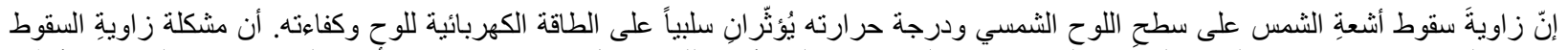

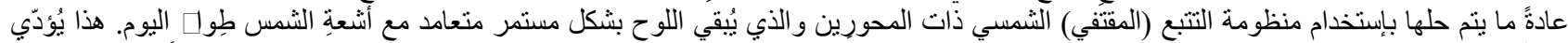

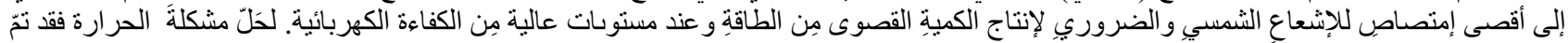

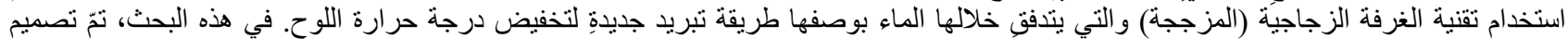

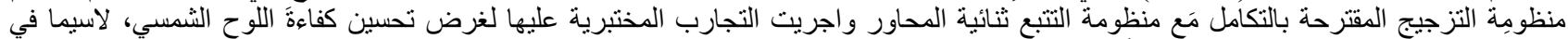

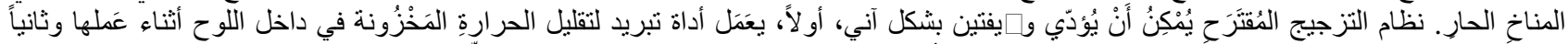

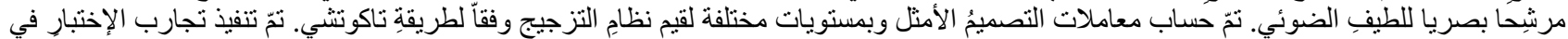

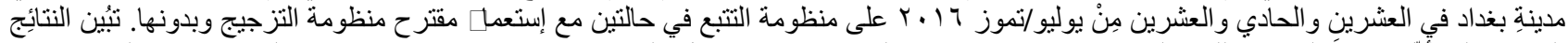

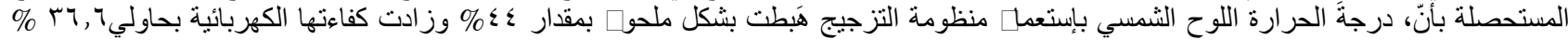

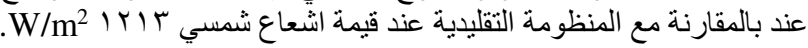

